\title{
Iterative Lösung und Fehlerabschätzung in der Ausgleichsrechnung
}

\section{Doctoral Thesis}

Author(s):

Läuchli, Peter

Publication date:

1959

Permanent link:

https://doi.org/10.3929/ethz-a-000103799

Rights / license:

In Copyright - Non-Commercial Use Permitted 
Prom. Nr. 2814

\title{
Iterative Lösung und Fehlerabschätzung in der Ausgleichsrechnung
}

\author{
VON DER \\ EIDGENÖSSISCHEN TECHNISCHEN HOCHSCHULE \\ IN ZÜRICH \\ $Z U R$ ERLANGUNG
}

DER WURDE EINES DOKTORS DER MATHEMATIK

GENEHMIGTE

PROMOTIONSARBEIT

VORGELEGT VON

PETER LÄUCHLI

DI PL. PHYS I KE R

von A A R U

Referent: Herr Prof. Dr. E. Stiefel

Korreferent: Herr Prof. Dr. F. Kobold

BASEL

Buchdruckerei Birkhäuser AG.

1959 
angegeben werden. Was in weiteren Schritten noch dazukäme, wäre offenbar sehr fragwürdig. Im 8 . Schritt sollten beide Zahlenfolgen theoretisch denselben Wert erreichen.

\begin{tabular}{|l|l|l|}
\hline Schritt $i$ & $p_{11}$ (vermittelnd) & $p_{11}$ (bedingt) \\
\hline 0 (Start) & 0 & 1 \\
1 & 0,1119 & 1 \\
2 & 0,1558 & 1 \\
3 & 0,1564 & 0,9991 \\
4 & 0,3119 & 0,9920 \\
5 & 0,3151 & 0,9900 \\
6 & 0,8093 & 0,9899 \\
7 & 0,8810 & 0,9899 \\
8 & 0,9300 & 0,9898 \\
\hline
\end{tabular}

\section{LITERATURVERZEICHNIS}

[1] E. Stiefel, Ausgleichung ohne Aufstellung der Gaußschen Normalgleichungen, Wissensch. Z. techn. Hochschule Dresden 2, 441 (1952/53).

[2] J. L. Synge, The Hypercircle in Mathematical Physics (Cambridge University Press, 1957).

[3] R. Zurmuenl, Praktische Mathenatik für Ingenieure und Physiker, 2 Aufl. (Springer, Berlin 1957).

[4] E. Stiffel, Úber einige Methoden der Relaxationsrechnung, Z. angew. Math. Phys. 3, 1 (1952).

[5] E. StIEFel, Relaxationsmethoden bester Strategie zur Lösung linearer Gleichungssysteme, Comm. math. helv. 29, 157 (1955).

[6] M. R. Hestenes und E. Stiffel, Methods of Conjugate Gradients for Solving Linear Systems, J. Res. NBS 49, No. 6, 409 (1952).

[7] R. Courant und D. Hilbert, Methods of Mathematical Physics, 1st English ed. (Interscience Publishers Inc., New York 1953), besonders S. $252 \mathrm{ff}$.

[8] W. JoRDAN und O. EGGERT, Handbuch der Vermessungskunde, 1. Bd., 8. Aufl. (J. B. Metzlersche Verlagsbuchhandlung, Stuttgart 1935), S. $225 \mathrm{ff}$.

\section{Summary}

The paper begins with a short description of the theory of overdetermined linear systems (Ausgleichsrechnung), using the notation of matrix-calculus.

The solution of such systems by means of relaxation-methods is then discussed. In particular a broad description of the method of conjugate gradients is given. The algorithm avoids the use of the matrix of the normal equations.

Lastly the application of the 'method of the hypercircle', developed by SyNGE and others, to this problem of linear algebra is studied, with the aim of finding upper and lower bounds for the sum of the square residuals - this sum being a minimum for the solution of the system. To get these bounds, we need approximate solutions obtained as intermediate values in an iterative process. 